\title{
An Evolution of Tax Systems in Post-Independent Mauritius
}

\author{
Nirmal Kumar Betchoo
}

\begin{abstract}
This research paper evaluates the evolution of taxation in Mauritius which celebrates its fiftieth Independence anniversary in March 2018. It analyses the various forms of taxation that have been developed and implemented over the years in the country since its Independence in 1968. This work explains the application of different taxes affecting local taxpayers over the years but pays importance on their evolution as the economy progressed from a monocrop culture based on sugar cultivation to a sophisticated one where several pillars like textile, tourism and the financial services have been developed over the years. If taxation aims at generating revenue for the State, the researcher claims that it must ensure that tax gains should entail a good spending in developing infrastructure for social benefits and avoiding wastage on poorly-managed projects. There is also an insight into the new negative income tax that has recently been implemented in Mauritius which also claims that the government is also keen in addressing social issues like poverty within the tax systems in force in the country.
\end{abstract}

Index Terms-Evolution; Post-Independence; Tax Systems; Mauritius.

\section{INTRODUCTION}

It is firstly important to understand the basic importance of taxation in any country. The fact that the government taxes consumers and industry is based upon the prospect for the State to earn money that might be reinvested in the economy to provide better services to the community. Johansson et al (2008) suggest that tax systems are primarily aimed at financing public expenditures [1]. They are also used to promote key objectives like equity, and address social and economic concerns. Taxation is intended to raise the necessary funds for public expenditure, to redistribute income, to stabilise the economy, to overcome externalities, to influence the allocation of resources, while at the same time should be supportive to the economic growth [2]. In countries that are endowed with natural resources, governments may own primary and secondary industries and this allows them to get high revenues at source and then complement further earnings through taxation. Taxes are a credible policy, yielding the government some revenue while being transparent and simple to administer [3]. The case of Mauritius is different given that the island-nation is not endowed with rich physical resources and hence cannot generate direct revenue. The wealth of the nation is measured in terms of revenues created from production in the different sectors, namely the private sector, including the

Published on April 5, 2018

Dr Nirmal Kumar Betchoo is Dean of Faculty of Business and Management at the Université des Mascareignes, Republic of Mauritius. (email:nbetchoo@udm.ac.mu ) commitment of government to providing essential services like health, education and social security to the population.

There has always been a tax system in the Mauritian economy. This has originated from traditional taxation systems like export levy on sugar producers, company tax and income tax collected from consumers. In a span of fifty years that followed the access of Mauritius to independence in 1968, there have been developments in tax administration and systems at the national level. Ramdoo (2014) comments that in 1968, at the dawn of its independence, Mauritius was a sugar-based monoculture, with a stagnating GDP per capita of barely US\$200. Agriculture made up $25 \%$ of the gross domestic product (GDP) and sugar alone accounted for over $90 \%$ of total exports [4]. Unemployment was rampant, estimated at $20 \%$. Today, the contrast is striking: the economic landscape is completely transformed. GDP per capita is estimated at slightly above US\$9,000, and the country has a diversified. In parallel, it could be also considered that tax systems encouraging revenue collection have been instrumental in promoting growth. This article sums up the evolution of tax systems in the country since Independence by stating that such a system has developed over the years to become a suitable model with higher level of sophistication in its administration while it also points out the possible disparity between efficient tax earning system and wastage generated as a result of a misuse of taxcollected money.

\section{TAXATION AT INDEPENDENCE AND IN THE $1970 \mathrm{~S}$}

Taxation has always been part of the economic system in Mauritius and in most societies except those more in favour of religion-based financial systems that technically avoid tax. Direct taxes existed in industry especially the sugar and tea industries that characterised the early secondary industries of the economy. Sugar producers who were the largest ones at the time of Independence had to pay the export levy (taxe de sortie) on exports including the company tax. Export levies were based on the volume of exports and the revenues earned during trade exchange with the former European Economic Community (EEC). Company tax affected mostly secondary and some emerging tertiary sectors like banking and commerce based on the revenues earned during the financial year. This taxation was effected by the former Income Tax department that relied on paper documents attesting business undertaken by the industries. At times when the economy was in difficulty, sugar exporters urged the government to either lower or remove the export levy which the State had to undertake as a social measure. Piermartini (2004) inferred that export taxes might have long-run inflationary consequences on the 
economy. Such taxes could depress the incentive to invest in the production of the taxed commodity [5].

Income tax was another source of government revenue during the post-Independence years. Government favoured a progressive tax based on annual earnings of consumers which was payable as at $30^{\text {th }}$ September ending the financial year. This tax system had a basic tax rate of $5 \%$ that progressed up to $35 \%$ for the highest income earners. Basically, the average tax quantum fell in the range of 10 to $15 \%$. Since the early income tax system was based on paper documents, it was a burden for many taxpayers to fill the form and the risk of non-declaration of revenue was high. Tax avoidance resulted in the existence of high liquidity in the monetary system as well as 'black money' that might have been earned from dubious sources. Tax evasion was a possibility at that time due to inherent difficulties to track bad taxpayers. Eriksen and Fallan (1996) concluded that a fruitful means of reducing tax evasion is to provide more tax knowledge to as many taxpayers as possible in order to improve their tax ethics and perceptions of fairness and equity [6].

The third importance source of tax funding came from residential property tax. This mainly concerned urban residents who had to pay an annual tax concerning their residential property. Since municipalities were concerned with the well-being of such residents namely the collection of garbage, waste and refuse including the provision of electricity for street lighting, such tax demarcated urban livelihood from rural residents who did not pay such a tax. There was a time when the rural tax was to be implemented but that failed as it was a hot political issue.

\section{ThE SALES TAX IN THE $1980 \mathrm{~S}$}

The coming of a new government that preceded the Labour Party holding power since Independence found it necessary to introduce a Sales tax as from end of 1982 [7]. The economy was in dire difficulty and reserves were near empty. The then Financial Minister, Paul Bérenger, introduced a sales tax of $5 \%$ on commodities. This was a first direct tax that affected all Mauritians causing a price rise for all products. This tax was implemented following resentment and grievances from taxpayers but became institutionalised over the years. Such a Sales tax affected consumption namely from the low-income earners who had no choice to accept funding the State.

As the economy developed and a first economic miracle took place between 1986 and 1990, consumption improved including wealth creation from the setting up of emerging industries like the textile industry. By the end of the 1990s, a re-engineering of the Sales tax was envisaged. In practical policy terms, a greater revenue shift could probably be achieved into consumption taxes. However, with consumption taxes being less progressive than personal income taxes, or even regressive, a shift in the tax structure from personal income to consumption taxes would reduce progressivity [8].

\section{THE VALUE-AdDed TAX}

A modern economy demanded a re-engineering of taxation. In a more sophisticated economic system, there needed be some mechanism to tax evenly all aspects ranging from the sourcing of raw materials, the production process, product creation, distribution and purchase of commodities. The Value-added Tax concept works on the principle that it shall be charged on any supply of goods or services made in Mauritius, where it is a taxable supply made by a taxable person in the course or furtherance of any business carried on by him (VAT Act 2003). Government wanted to ensure that such taxation was applicable to each level of the production activity where traceability of production and taxation would be transparent [9]. This resulted in the development of the value-added tax (VAT) that was introduced by the Labour government in power. This was a rise in taxation of $3 \%$ which gradually fixed the tax level to $10 \%$ in eventual budget preparations until it attained the $15 \%$ mark. At a certain time, a possibility of raising the VAT to $18 \%$ was envisaged but this was subject to serious reserves from trade unions.

\section{THE COMPUTERISATION OF TAXATION}

From a paper-based bureaucratic activity of calculating taxation, processing information and ensuring effective payments, the tax system went through the desired development under the Information diffusion that was meant to computerise all systems in government and later industry. The creation of the Mauritius Revenue Authority in 2004 led to a harmonisation in tax collection at the national level. Firstly, individual customer accounts were traceable with computerisation. Taxes were collected at various levels and in various ways. Since customer accounts were connected to banking systems, there was higher possibility of monitoring earnings. Additionally, the use of Tax Account numbers and digitalised customer account systems ensured improved possibility for the new tax systems to track payers and see that revenues could be taxed more accurately.

Secondly, the Corporate tax turned out as a model of taxation in the Mauritian tax framework. The current $15 \%$ corporate tax ensures that all companies are firstly entitled to make annual returns, large businesses are obliged to publish their annual Statement of Accounts while the quantum of taxation applies to all businesses involved in profit creation. The tax reform undertaken in 2006 set a Uniform Corporate Tax and Personal Income Tax rate at 15 $\%$. The motivation behind this was that the Flat tax model had the desirable trait of minimising economic distortions caused by specific taxes on special-interest driven initiatives, [10]. Higher levels of jurisdiction and tax accountability resulting from the existence of foreign companies in the domestic economy have fostered higher levels of investigation and accountability in tax collection. Systems have also become complex through the existence of the double-tax avoidance agreement (DTAA) whereby companies operating from Mauritius and eventually investing in India might have ether to forgo taxation in either country.

This system has been recently being subject to criticisms mainly from the Indian government following substantive reforms as well. Singh (2016) stated that the amendment of the treaty was a move in line with the government's initiatives to curb black money in the system, money laundering and tax avoidance [11]. The Finance Ministry 
statement held the protocol would tackle issues of treaty abuse and round-tripping of funds attributed to the IndiaMauritius treaty, curb revenue loss, prevent double nontaxation, streamline the flow of investment, and stimulate the flow of exchange of information between India and Mauritius. It is also expected to discourage speculators and non-serious investors, and thereby reduce volatility in the market.

\section{NEGATIVE TAX AND ITS IMPACT ON LOW-INCOME EARNERS IN MAURITIUS}

If taxation merely depended upon the collection of money from businesses and consumers, a negative tax in the form of financial compensation has been recently adopted for low-income earners. Following the implementation of a minimum salary of Rs 9000 as from January 2018, government has decided to adopt a negative tax whereby a minimum quantum of Rs 100 is applied to those gaining less than Rs 9900 up to a maximum of Rs 1000 for employees in the income group of Rs 5000 or less. This incentive acts as a palliative for those earning less. Since the minimal salary is a reality now, the funding of the negative tax is likely to be less cumbersome for the State. The negative income tax for low-income employees that has been accompanied by a new solidarity levy of 5 percent for high-income earners is a step towards mitigating income inequality [12].

\section{ThE RIght BALANCE BETWEEN TAXATION AND WASTAGE}

In these fifty years since Mauritius gaining independence, this recall of tax evolution is essential as a structured revenue collection mechanism helps in furthering the development of the Mauritian economy. In Patonov and Stoilova's work (2012), their empirical results showed a clear and strongly expressed impact of the direct taxes on economy growth. This is due to efficiency gains of revenue accumulation through taxation of wealth. Government can raise revenue in two fundamentally different ways: by increasing the scope and size of the tax base, or by increasing the rates at which the base is taxed. Broadening the tax base often increases economic efficiency and growth by treating all forms of activity more similarly [13]. Equally, tax earnings help in funding public debt to make it reach an acceptable level in ratio terms compared to what the country actually produces-The Gross Domestic product. The big problem comes from the tax money invested in developing infrastructure, funding projects and paying for various expenses.

Mathur (2012) argues the government can incur massive additional expenditure only if it can raise commensurate revenue through taxation [14]. But if expenditure is financed by incurring debt liability, it might have disastrous consequences for the economy, besides imposing heavy interest payment liability. An alarming level of public expenditure financed by public and enterprise funding illustrates the wastage of money, the existence of 'white elephants', the non-respect of deadlines in key project management as well as a 'laisser-faire' attitude culminating in greater expenses. This might explain the onset of financial malpractices and to a larger extent corruption in finance. Over time other unfavourable consequences of corruption have been documented including increased costs of doing business, unfair allocation of public entitlements, poor quality consumer products and reduced public safety [15].

If on the one hand, the evolution of taxation shows a commendable effort in monitoring finance, chasing taxpayers and collecting tax money for economic advancement, the question of using such taxation efficiently still raises concern in a modern emerging economy that aims to become a high-income economy in a near future. The ride against the tide is challenging even in a tax-governed liberal economy. Zafar (2011) sums up that in terms of both revenue management and expenditures, fiscal policy in Mauritius has been proactive and that such policy has helped lay the foundation for management of volatility and robust growth. This research on tax systems clearly purports the impact of tax systems in Mauritius and how its scientific management has been of great benefit to the economy [16].

\section{ACKNOWLEDGMENTS}

The author wishes to acknowledge various sources for having provided him with valuable information namely the MCCI, local newspapers in Mauritius and websites that have provided him facts and figures that could be effectively used for discussing the issue in a confident manner.

\section{REFERENCES}

[1]. A. Johansson., C. Heady., J. Arnold., B. Brys., and L. Vartia. (2008) Tax and Economic Growth Economics Department Working Paper No.620, Organisation for Economic Co-operation and Development.

[2]. N. Patonov and D. Stoilova, (2012) An Empirical Evidence for The Impact of Taxation On Economy Growth in The European Union, Book of Proceedings - Tourism and Management Studies International Conference Algarve 2012 vol.3 ISBN 978-989-8472-250 .

[3]. R. Piermartini (2004) The Role of Export Taxes in the Field of Primary Commodities, World Trade Organisation.

[4]. I. Ramdoo. (2014) Economic transformation in Mauritius. GREAT Insights, Volume 3, Issue 5. May 2014.

[5]. K. Eriksen and L. Fallan, (1996). Tax knowledge and attitudes towards taxation: A report on a quasi-experiment. Journal of Economic Psychology, 17, 387-402.

[6]. K. Eriksen and L. Fallan, (1996). Tax knowledge and attitudes towards taxation: A report on a quasi-experiment. Journal of Economic Psychology, 17, 387-402.

[7]. Income Tax Act (1983) http://www.mra.mu Downloaded on $6^{\text {th }}$ February 2018.

[8]. OECD (2008) Tax and economic Growth, MENA-OECD Investment Programme.

[9]. VAT Act (2003). The Value-Added Tax Act, Government of

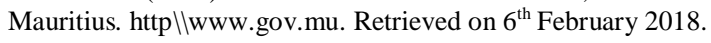

[10]. MCCI (2013) Memorandum On The 2013 Budget-Gearing towards a more competitive economy, Mauritius Chamber of Commerce and Industry.

[11]. S. Singh (2017) What the changes in the tax treaty with Mauritius mean for India investors? Indian Express, $12^{\text {th }}$ May 2017.

[12]. T. Deloitte (2017) Analysis Mauritius Budget 2017-2018, Addressing structural challenges to drive growth. https://www2.deloitte.com/mu/en/pages/tax/articles/mauritius-budget2017.html. Accessed on $2^{\text {nd }}$ February 2018.

[13]. CED.org (2016) The Federal Budget Deficit and the Public Debt, Committee for Economic Development.

[14]. B. Mathur (2012) India's Public Debt Explosion: Heading Towards Bankruptcy, Mainstream, VOL L, No 15, March 31, 2012.

[15]. S. Ackerman (1998) The Political Economy of Corruption - Causes and Consequences, Public Policy for the Private Sector Note No 74, World Bank

[16]. A.Zafar (2011) Mauritius, an economic success story, World bank. 


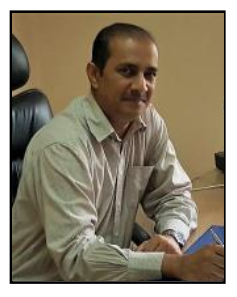

Dr Nirmal Kumar Betchoo is Dean of Faculty at the Université des Mascareignes. He holds a DBA (Switzerland), an MBA (Scotland) as well as finalist of the professional examinations of the Chartered Institute of Marketing and the Institute of Administrative Management (UK).

$\mathrm{He}$ is the author of 10 books published nationally and internationally. He has published over 50 peerreviewed articles in international refereed journals. $\mathrm{He}$ is external editor for the Journal of Mass Comminications (USA) and the European Scientific Journal (ESJ0. So far, he has reviewed some 50 papers. He attends both conferences held in
Mauritius and abroad particularly in Athens and Barcelona. He is panel specialist for the Tertiary Education Commission (TEC) in Mauritius for post-graduate programmes in management.

Dr Betchoo writes extensively for the local press where he has published lead papers out of some 125 articles he has published since 2012. His consultancy works include: Trainer for women entrepreneurs, Paper moderator for the University of Technology and the Mauritius Institute of training and Development, Supervisor for Ph. D students along with his 32 year teaching experience out of which 23 have been devoted to teaching excellence at the tertiary level. 